\title{
Anti-stress Effects of Tunisian Cymbopogon schoenanthus L. Ethanol Extract and Some of Its Active Compounds
}

\author{
Mahmoud Ben Othman ${ }^{1}$, Mohamed Neffati ${ }^{3}$ and Hiroko Isoda ${ }^{1,2}$ \\ 1. Alliance for Research on North Africa (ARENA), University of Tsukuba, 1-1-1 Tennodai, Tsukuba City, Ibaraki 305-8572, Japan \\ 2. Faculty of Life and Environmental Sciences, University of Tsukuba, 1-1-1 Tennodai, Tsukuba City, Ibaraki 305-8572, Japan \\ 3. Range Ecology Laboratory, Arid Land Institute of Medenine, Medenine 4119, Tunisia
}

\begin{abstract}
Many antioxidant rich phytochemical extracts are attracting interest as stress adaptogens. In this regard, several plants are used traditionally and clinically for the management of neurologic disorders. Here, the anti-stress properties of the ethanol extract of medicinal plant Cymbopogon schoenanthus (CSEE), which grows wild in Southern Tunisia, were investigated, as well as the effects of some of the extracted active compounds on $\mathrm{H}_{2} \mathrm{O}_{2}$-induced cytotoxicity, overproduction of reactive oxygen species (ROS) and adenosine triphosphate (ATP) depletion in human neuroblastoma SH-SY5Y cells. Whereas fluorescence intensity due to DCFH-DA (a marker of ROS production) in $\mathrm{H}_{2} \mathrm{O}_{2}$-treated SH-SY5Y cells was greater than that in untreated control cells, pretreatment with CSEE and its active compounds ameliorated $\mathrm{H}_{2} \mathrm{O}_{2}$-induced ROS production. Moreover, $\mathrm{H}_{2} \mathrm{O}_{2}$ at $150 \mu \mathrm{M}$ significantly decreased intracellular ATP levels in SH-SY5Y cells, and pretreatment with CSEE and its active compounds buffered this effect. These in vitro results demonstrate the potential of CSEE to protect against stress-associated disorders.
\end{abstract}

Key words: ATP levels, $\mathrm{H}_{2} \mathrm{O}_{2}$, medicinal plant, reactive oxygen species, stress.

\section{Introduction}

Stress is a part of everyday life, and myriad scientific, psychological, medical and even social experts work toward defining and reducing its causes and deleterious effects. Stress alters many physiologic responses, sometimes leading to pathologic outcomes [1]. For example, various stress paradigms significantly affect learning and memory functions and intensify fear memory in mice $[2,3]$. Stress-induced effects likely arise through a complex interaction of various factors and mechanisms, including decreases in the levels of central neurotransmitters, neurohormonal factors [4] and neurotrophic factors [5], and increases in free radical generation and oxidative damage in the central nervous system [6]. Furthermore, a variety of disease states, including ischemia-reperfusion injury and

Corresponding author: Hiroko Isoda, professor, research field: food biotechnology. hyperoxia, are associated with increased mitochondrial oxidant generation, mitochondrial oxidative injury or ATP depletion $[7,8]$.

The central nervous system consumes about $20 \%$ of energy in the body, using glucose as its main source of fuel [9]. Synapses within the brain are thought to be primary sites of ATP consumption. In addition, ATP is an important extracellular signaling molecule that is released from cells during particular physiologic and pathologic processes, such as neurotransmission, hypotonic stress and cell injury due to inflammation and tumor necrosis $[10,11]$.

Free radicals are molecules that possess unpaired electrons and arise as necessary intermediates in mitochondrial metabolism. However, some radicals or oxidants, when produced outside these tightly controlled biochemical pathways, can induce specific modifications to biomolecules, thus altering their functions and so contributing to the development of 
disease [12]. Whereas a low level of reactive oxygen species (ROS) promotes cell proliferation through the activation of growth-related signaling pathways in normal cells, the biological consequences of excess mitochondrial ROS production are likely substantial. In particular, hydrogen peroxide $\left(\mathrm{H}_{2} \mathrm{O}_{2}\right)$ is one of the main ROS produced during the redox process. $\mathrm{H}_{2} \mathrm{O}_{2}$ enhances carcinogenesis and cancer progression [13], and can cause lipid peroxidation and DNA damage, thus inducing apoptosis in many different cell types [14]. In this context, there is growing interest in the search for novel compounds for the treatment of stress, which is considered as a very harmful condition that contributes to numerous pathologies, including cancer, allergy, cardiovascular abnormalities and skin diseases [15-18].

Recent developments in technology and several chemical analyses have revealed that the health-promoting biologic properties attributed to many plant species are in fact due to active compounds that are produced during secondary vegetal metabolism (for example, polyphenols, flavonoids, tannin, essential oils). These secondary metabolites have a wide spectrum of biological activities, including potential anti-inflammatory, anticancer, anti-allergic and anti-stress effects [19-23]. Despite advances in the development of synthetic products, natural medicine is a valuable field of research, because the biological diversity of nature yields a wide range of bioactive molecules [24].

Humankind has long made use of plants to alleviate suffering and disease. For example, herbal medicines are an important part of the culture and traditions of the African continent, where approximately 122 drugs originating from 94 species have been discovered through ethnobotanical leads [25]. Belonging to the family Poaceae (Gramineae), the genus Cymbopogon comprises 56 species [26], which are often aromatic and are distributed widely throughout the Mediterranean area. The focus of the current study, $C$. schoenanthus, is a sub-spontaneous grass and aromatic culinary herb of Southern Tunisia, where it is known locally as "El bekherai." This plant is common in north and west of tropical Africa, the Arabian Peninsula and Egypt, where it is used in several preparations of meat and salad and is served with tea because of its pleasant aroma [27]. As a medicinal plant, C. schoenanthus is used for the treatment of rheumatism and fever [28], as a diuretic and insecticide (it is active against termites and the bruchid beetle Callosobruchus maculates) [29] and as a poultice to cure wounds in dromedaries [30]. In various North African countries, C. schoenanthus is used as an anti-anorexic and appetite stimulant, an anti-abortive, an anti-convulsive and sedative preparation and a digestive or laxative agent [31].

In this paper by using an in vitro bioassay, the anti-stress effects of the ethanol extract of $C$. schoenanthus (CSEE) and some active compounds by focusing on their role in protecting SH-SY5Y cells (a human neuroblastoma line) against $\mathrm{H}_{2} \mathrm{O}_{2}$-induced cytotoxicity, ROS production and ATP depletion were investigated.

\section{Materials and Methods}

\subsection{Cell Culture}

Human neuroblastoma SH-SY5Y cells were cultured in 1:1 mixture of Dulbecco's minimum essential medium (Sigma, USA) and Ham's F-12 nutrient mixture (Sigma, USA). This mixture was supplemented with $15 \%(\mathrm{v} / \mathrm{v})$ fetal bovine serum (Sigma), 1\% (v/v) non-essential MEM amino acids and $1 \%$ penicillin $(5,000 \mu \mathrm{g} / \mathrm{mL})$-streptomycin $(5,000$ $\mathrm{IU} / \mathrm{mL}$ ) solution (ICN Biomedical). The cells were cultured in $100 \mathrm{~mm}$ dishes and passaged at $80 \%$ confluence twice weekly by trypsinization using $0.25 \%$ trypsin-EDTA (Sigma). In addition, the medium was changed every other day, and the cells were incubated at $37{ }^{\circ} \mathrm{C}\left(5 \% \mathrm{CO}_{2}\right)$.

\subsection{Determination of Cell Viability}

Cells were seeded in 96-well plates at a density of 2 
$\times 10^{4}$ cells/well, allowed to attach for $24 \mathrm{~h}$ and subsequently treated with various concentrations of $\mathrm{H}_{2} \mathrm{O}_{2}$. After an additional $24 \mathrm{~h}$ of incubation, cell viability was evaluated by using 3-(4,5dimethylthiazol-2-yl)-2,5-diphenyltetrazolium bromide (MTT, $5 \mathrm{mg} / \mathrm{mL}$ in PBS), as described previously [32]. Briefly, $10 \mu \mathrm{L}$ of MTT solution was added to each well, and the plate was incubated for $6 \mathrm{~h}$ at $37{ }^{\circ} \mathrm{C}$ in a 95\% humidified air with $5 \% \mathrm{CO}_{2}$ incubator. Then 100 $\mu \mathrm{L} 10 \%(\mathrm{w} / \mathrm{v})$ sodium dodecyl sulfate was added to each well, the plate was incubated overnight and the absorbance at $570 \mathrm{~nm}$ was determined. The control wells, which contained cultured cells with medium only, were considered to have $100 \%$ cell viability; otherwise, viability was reported as a percentage of the control value. For each experiment, each treatment was performed in triplicate.

\subsection{Determination of ROS Production in $\mathrm{H}_{2} \mathrm{O}_{2}$-Stressed SH-SY5Y Cells}

Widely used to evaluate cellular oxidative stress, the lipophilic and non-fluorescent compound dihydrodichlorofluorescein diacetate (H2DCF-DA) passes through the plasma membrane, is de-esterified to a hydrophilic alcohol (H2DCF), and then is oxidized to fluorescent 2',7'-dichlorofluorescein (DCF) through a process generally considered to involve ROS [33]. To assess the effect of CSEE on the production of ROS in $\mathrm{H}_{2} \mathrm{O}_{2}$-stressed cells, $\mathrm{SH}-\mathrm{SY} 5 \mathrm{Y}$ cells were seeded at $2 \times 10^{4}$ cells/well in 96-well plates and allowed to attach for $24 \mathrm{~h}$. The cells then were treated with CSEE for $24 \mathrm{~h}$. After $24 \mathrm{~h}$, cells were treated with H2DCF-DA for $60 \mathrm{~min}$ and then treated with $150 \mu \mathrm{M} \mathrm{H} \mathrm{H}_{2} \mathrm{O}_{2}$ for $60 \mathrm{~min}$ or $30 \mathrm{~min}$, after which the fluorescence in each well was measured by using a multi-detection microplate reader (Power Scan HT, Dainippon Pharmaceutical, Japan) at wavelengths of 480/530 $\mathrm{nm}$ (excitation/emission). Fluorescence was reported as a percentage of that in the untreated control.

\subsection{Measurement of Intracellular ATP Content}

Determination of intracellular ATP levels was based on the luciferin-luciferase system. SH-SY5Y cells were seeded at $2 \times 10^{4}$ cells/well in 96-well plates and allowed to attach for $24 \mathrm{~h}$ at $37{ }^{\circ} \mathrm{C}$. The cells were treated with mixtures of gallic acid (Sigma, USA), ferulic acid (LKT Laboratories) and trans-cinnamic acid (LKT Laboratories), which have been identified as components of CSEE, for $24 \mathrm{~h}$. After this incubation, the cells were exposed to 150 $\mu \mathrm{M} \mathrm{H}_{2} \mathrm{O}_{2}$ for $3 \mathrm{~h}$. Finally, the luminescence in each well was measured by using a multi-detection microplate reader (PowerScan HT, Dainippon Pharmaceutical) at 480/530 $\mathrm{nm}$ (excitation/emission), and the activity was reported as a percentage of that of the untreated control.

\subsection{Statistical Analysis}

All data are expressed as mean \pm standard error of mean (SEM) and the significance of differences was calculated by using Student's $t$ test. Statistical significance was defined as $P<0.05$.

\section{Results}

\subsection{CSEE Protecting SH-SY5Y Cells against $\mathrm{H}_{2} \mathrm{O}_{2}$-Induced Toxicity}

To determine the non-cytotoxic concentrations of CSEE, human neuroblastoma SH-SY5Y cells were treated with CSEE at $1.5,15$ and $150 \mu \mathrm{g} / \mathrm{mL}$ for $48 \mathrm{~h}$. CSEE did not affect SH-SY5Y cells viability at 1.5 $\mu \mathrm{g} / \mathrm{mL}$ and $15 \mu \mathrm{g} / \mathrm{mL}$, and decreased viability only slightly and non-significantly at $150 \mu \mathrm{g} / \mathrm{mL}$ (data not shown). To obtain an appropriate $\mathrm{H}_{2} \mathrm{O}_{2}$ concentration for use in later assays, SH-SY5Y cells were treated for $24 \mathrm{~h}$ with $\mathrm{H}_{2} \mathrm{O}_{2}$ at concentrations that ranged from $50 \mu \mathrm{M}$ to $250 \mu \mathrm{M}$. Preliminary experiments revealed that $150 \mu \mathrm{M} \mathrm{H}_{2} \mathrm{O}_{2}$ reduced the viability of SH-SY5Y cells by $40 \%$ after $24 \mathrm{~h}$ exposure (Fig. 1), and an $\mathrm{H}_{2} \mathrm{O}_{2}$ concentration of $150 \mu \mathrm{M}$ was selected to evaluate the protective effects of CSEE on cell viability. 


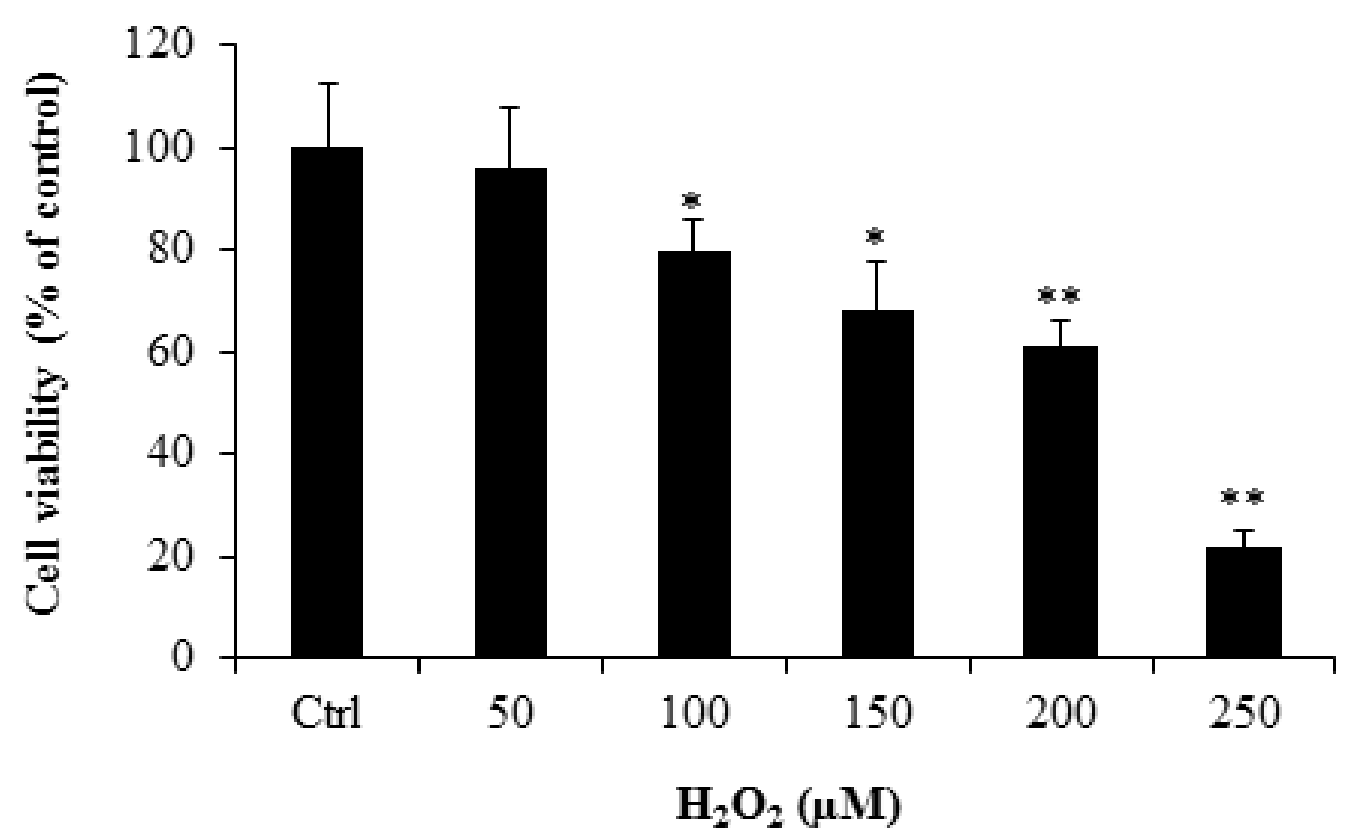

Fig. 1 SH-SY5Y cells seeded at $2 \times 10^{4}$ cells/well in 96-well plates for $24 \mathrm{~h}$ incubation and then treated with $\mathrm{H}_{2} \mathrm{O}_{2}(0$ (control), $50,100,150,200$ and $250 \mu \mathrm{M})$ for $24 \mathrm{~h}$.

Cell viability was determined by using MTT assay. Each bar represents the mean \pm standard deviation of three independent trials.

*: significant difference at $P<0.05$; **: significant difference at $P<0.01$ vs. control group by Student's $t$ test.

Pre-treatment of SH-SY5Y cells with CSEE $(7.5,15$ and $30 \mu \mathrm{g} / \mathrm{mL}$ ) for $12 \mathrm{~h}$ or $24 \mathrm{~h}$ significantly and dose-dependently improved cell viability in $\mathrm{H}_{2} \mathrm{O}_{2}$-treated cells compared with that of CSEE-untreated control cells.

\subsection{Measurement of Intracellular ROS Production}

The effect of CSEE on ROS production in $\mathrm{H}_{2} \mathrm{O}_{2}$-treated SH-SY5Y cells was estimated by using the fluorescent dye H2DCFH-DA. The fluorescence intensity of cells treated with $150 \mu \mathrm{M} \quad \mathrm{H}_{2} \mathrm{O}_{2}$ (vehicle-only control) was increased $(P<0.01)$ to $147 \%$ and $168 \%$ of that of untreated controls after 60 min and $30 \mathrm{~min}$ of incubation, respectively (Figs. 2a and $2 b$ ). In comparison, pretreatment of the cells with CSEE $(7.5,15$ and $30 \mu \mathrm{g} / \mathrm{mL})$ decreased $(P<0.01$ for all comparisons) the $\mathrm{H}_{2} \mathrm{O}_{2}$-induced accumulation of ROS relative to that in CSEE-untreated cells (Fig. 2).

\subsection{Effects of Mixtures Components of CSEE on $\mathrm{H}_{2} \mathrm{O}_{2}$-Induced ATP Depletion in SH-SY5Y Cells}

The results showed that exposure to $150 \mu \mathrm{M} \mathrm{H}_{2} \mathrm{O}_{2}$ significantly decreased the intracellular ATP level in SH-SY5Y cells to $70 \%$ of that in untreated control cells (Fig. 3). To assess the effects of various concentrations of three components of CSEE-gallic acid, ferulic acid and trans-cinnamic acid on intracellular ATP levels in SH-SY5Y cells, four mixtures of these compounds (M1, M2, M3 and M4) were prepared (in each mixture, at least one or two compounds were mixed). Whereas M1 and M2 had no effect on ATP production, pretreatment with M3 maintained the ATP levels of $\mathrm{H}_{2} \mathrm{O}_{2}$-stressed SH-SY5Y cells at $90 \%$ of those in vehicle-only control $(P<0.05)$. Pretreatment with M4 also yielded a protective effect on intracellular ATP levels, which were $80 \%$ of those of the controls.

\section{Discussion}

Psychiatric conditions, especially stress and depression, are among the most common mood-associated pathologies treated with complementary and alternative therapies [34, 35]. This prevalence is associated with a worldwide increasing trend of coupling primary 
healthcare with traditional medicine, which offers a "green image," cultural significance and accessibility to all societal categories [36]. In this regard, phytochemicals, botanicals and plant extracts are gaining a lot of interest as complementary supplements to mitigate oxidative stress.

Chronic exposure to stress is well known to promote free radical generation and increased ROS levels in the body [6], and oxidative stress is a key factor in neuronal cell death and damage [37]. ROS

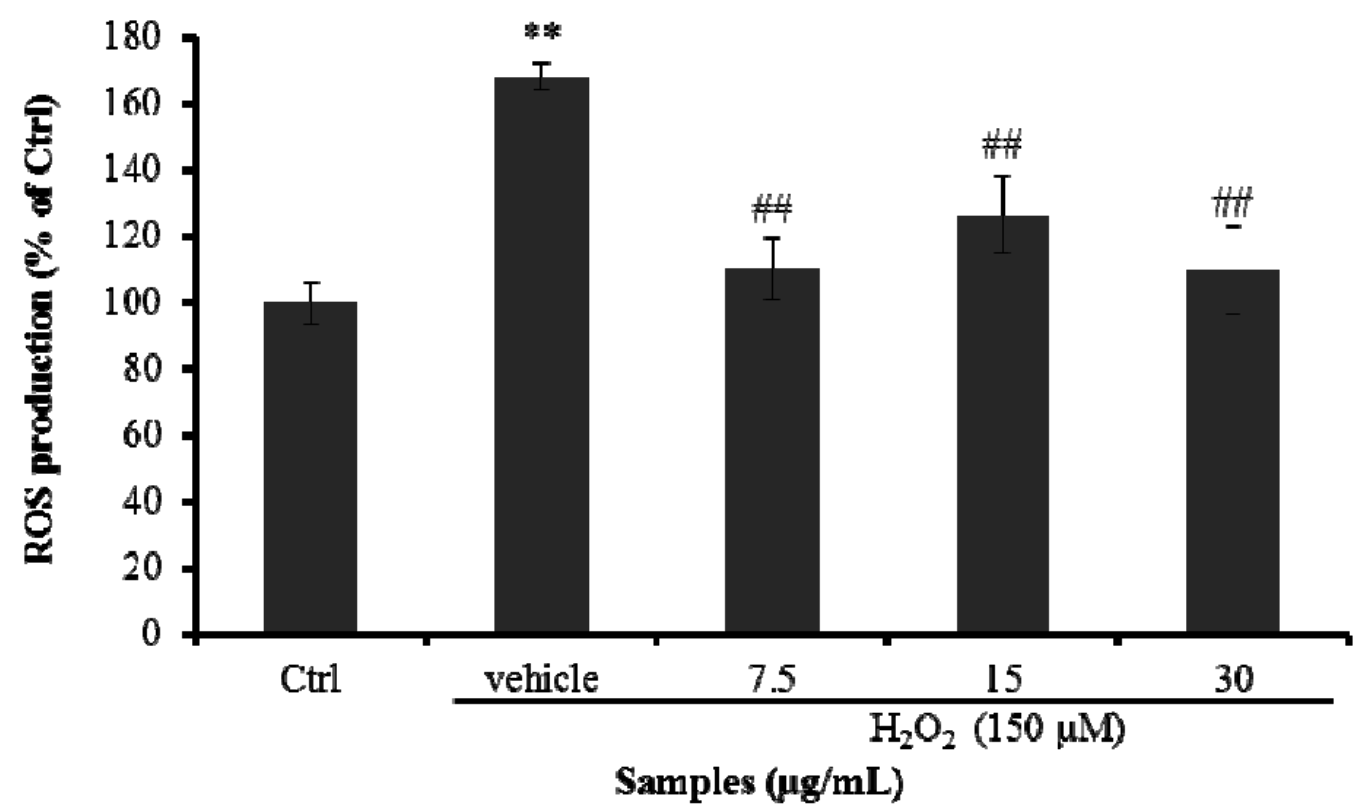

(a) Expose to $150 \mu \mathrm{M}$ of $\mathrm{H}_{2} \mathrm{O}_{2}$ for $30 \mathrm{~min}$

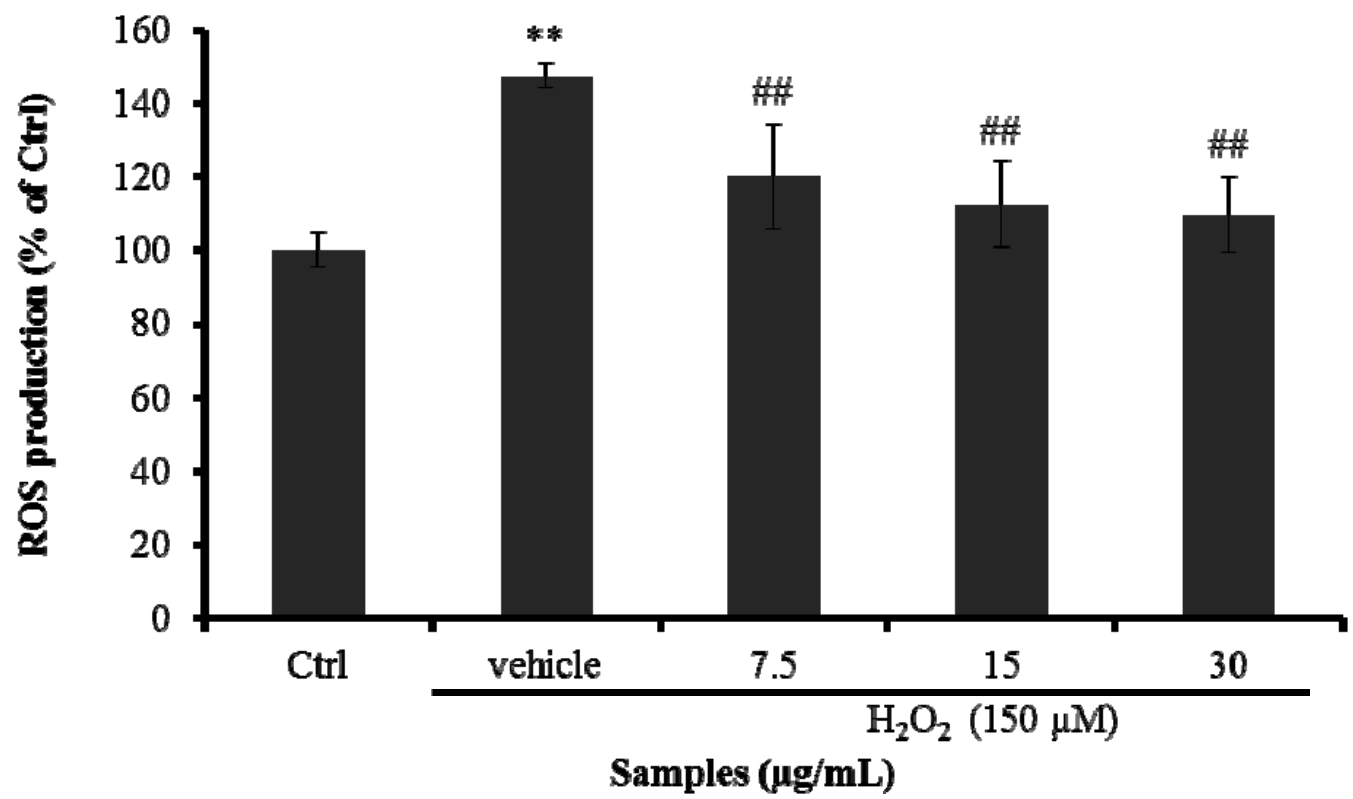

(b) Expose to $150 \mu \mathrm{M}$ of $\mathrm{H}_{2} \mathrm{O}_{2}$ for $60 \mathrm{~min}$

Fig. $2 \mathrm{H}_{2} \mathrm{O}_{2}$-induced ROS production in SH-SY5Y cells incubated with CSEE (0, vehicle only, 7.5, 15 and $30 \mu \mathrm{g} / \mathrm{mL}$ ) for 24 $h$ and then exposed to $150 \mu \mathrm{M}$ of $\mathrm{H}_{2} \mathrm{O}_{2}$ for $30 \mathrm{~min}$ (a) or $60 \mathrm{~min}(\mathrm{~b})$.

Results are given as means \pm standard deviation of three independent experiments; each experiment contained triplicate samples. **: significant difference at $P<0.01$ vs. untreated control group; ${ }^{\# \#}$ : significant difference at $P<0.01$ vs. vehicle-only control (cells treated with $\mathrm{H}_{2} \mathrm{O}_{2}$ only) by Student's $t$ test. 


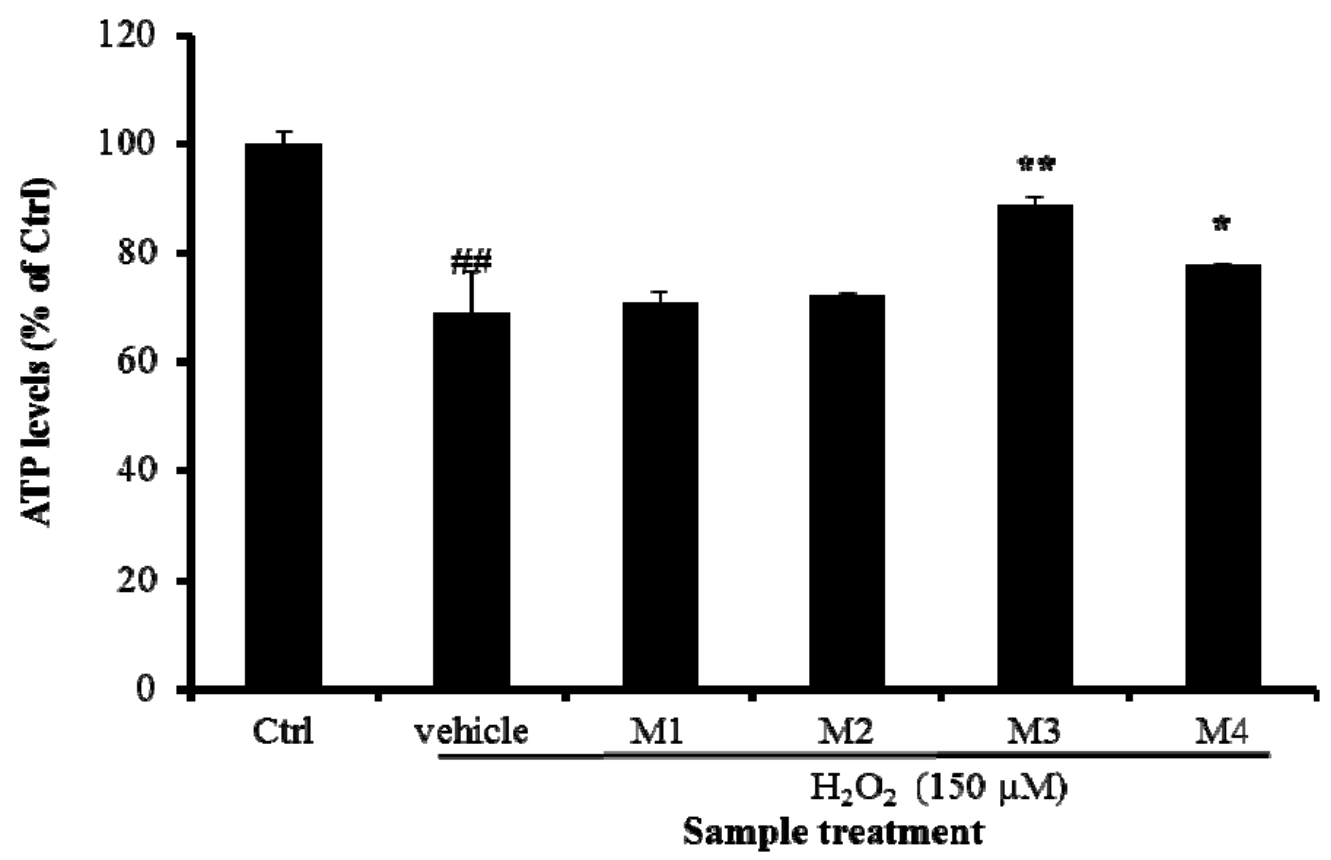

Fig. 3 Effects of $\mathrm{H}_{2} \mathrm{O}_{2}$-induced ATP depletion in SH-SY5Y cells incubated with mixtures of compounds identified in CSEE (M1-M4) for $24 \mathrm{~h}$ and then exposed to $150 \mathrm{\mu M} \mathrm{H}_{2} \mathrm{O}_{2}$ for $3 \mathrm{~h}$.

Results are given as means \pm standard deviation of three independent experiments; each experiment contained triplicate samples.

\#\#: significant difference at $P<0.05$ vs. untreated control group; *: significant difference at $P<0.05$ vs. vehicle-only control; **: significant difference at $P<0.01$ vs. vehicle-only control by Student's $t$ test.

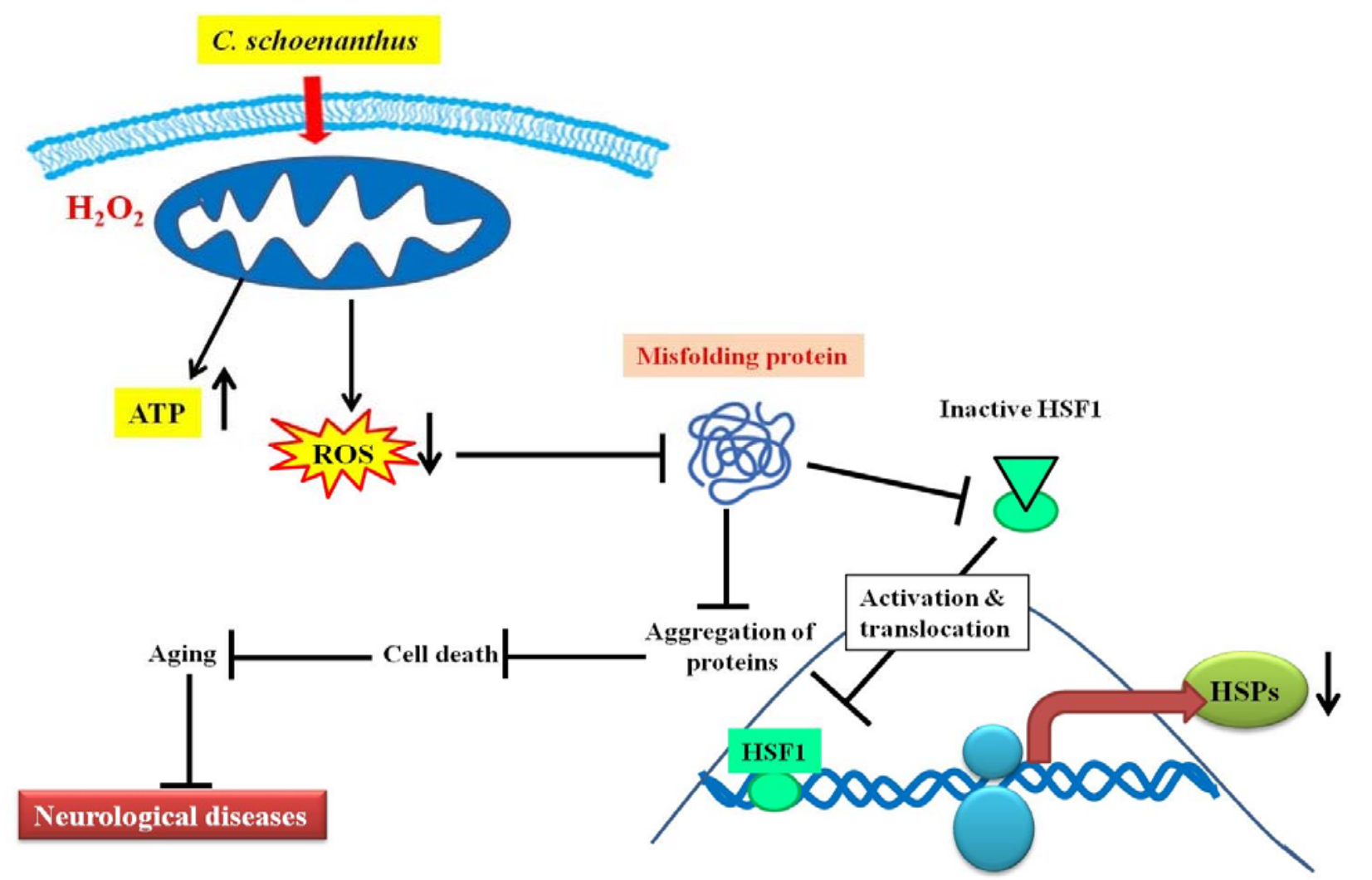

Fig. 4 Schematic diagram illustrating possible effects of CSEE on ROS and ATP production in $\mathrm{H}_{2} \mathrm{O}_{2}$-stressed $\mathrm{SH}$-SY5Y cells. 
are generated as a result of normal intracellular metabolism in mitochondria and peroxisomes and from a variety of cytosolic enzyme systems in animal and human cells [38, 39]. In addition, at low concentrations, ROS have several beneficial and necessary roles, including those in detoxification reactions accomplished by cytochrome P-450 complexes, the elimination of cancerous cells through the activation of apoptosis, cellular responses against infectious agents, cellular signaling pathways and the induction of mitogenic responses [40]. However, overproduction of ROS can induce harmful intracellular effects associated with various neurologic diseases and aging [39]. Moreover, the reactions of excess ROS with macromolecules can lead to DNA mutations, changes in the structure and function of proteins and peroxidative damage of cell-membrane lipids [41]. The $\operatorname{ROS}\left(\mathrm{H}_{2} \mathrm{O}_{2}\right)$ can diffuse through cell membranes and other organelles to react with various intracellular targets, trigger lipid peroxidation and oxidize proteins and DNA [42]. Furthermore, several studies have shown an increase in ROS production following $\mathrm{H}_{2} \mathrm{O}_{2}$ treatment $[13,43]$.

Given these effects of stress on ROS, antioxidant therapy might be an effective strategy to protect the human body against stress-mediated pathologies.

Most studies dealing with natural antioxidants have focused on the action of flavonoids. In addition to flavonoids, polyphenols, such as caffeic acid, ferulic acid and ellagic acid, occur at high concentrations in several foods and have antioxidant potential [44]. In this study, an increase of ROS and a reduction of ATP level was noticed when cells were exposed to $\mathrm{H}_{2} \mathrm{O}_{2}$. As shown in Fig. 4, the treatment of cells with $C$. schoenanthus prevented these disruptions and reduced the ROS production causing a decrease in HSPs expression genes.

\section{Conclusions}

It can be confirmed here that the ROS $(150 \mu \mathrm{M}$ $\mathrm{H}_{2} \mathrm{O}_{2}$ ) had deleterious effects on the viability, ROS generation and ATP production of SH-SY5Y cells, a human neuroblastoma line. Trough in vitro model to assess the potential neuroprotective effects of CSEE and three of its polyphenol components - gallic acid, ferulic acid and trans-cinnamic acid on $\mathrm{H}_{2} \mathrm{O}_{2}$-stressed cells, findings demonstrated that CSEE and some of its components alleviated the toxic effects of $\mathrm{H}_{2} \mathrm{O}_{2}$ exposure by reducing ROS production and increasing cell viability and intracellular ATP levels in the model system. The mechanisms underlying the anti-stress effect of CSEE, as well as the component proteins that accomplish this effect, are unknown but may be related to the ability of phenolic acids (e.g., gallic acid, ferulic acid, and trans-cinnamic acid) to prevent a decrease in ATP levels after $\mathrm{H}_{2} \mathrm{O}_{2}$ exposure. Future studies will be needed to investigate the specific effects of gallic acid, ferulic acid and trans-cinnamic acid on the activities of antioxidant enzymes in $\mathrm{H}_{2} \mathrm{O}_{2}$-stressed cells.

\section{Acknowledgments}

This work was supported in part by the Japan Science and Technology Agency (JST) and the Japan International Cooperation Agency (JICA) under a Science and Technology Research Partnership for Sustainable Development (SATREPS) project.

\section{References}

[1] Chrousos, G. P. 1998. "Stress as a Medical and Scientific Idea and Its Implication." Adv. Pharmacol. 42: 552-6.

[2] Nijholt, I., Farchi, N., Kye, M., Sklan, E. H., Shoham, S., Verbeure, B., Owen, D., Hochner, B., Spiess, J., Soreq, H., and Blank, T. 2004. "Stress-Induced Alternative Splicing of Acetylcholinesterase Results in Enhanced Fear Memory and Long-Term Potentiation." Mol. Psychiatry 9 (2): 174-83.

[3] Das, A., Rai, D., Dikshit, N., Palit, G., and Nath, C. 2005. "Nature of Stress: Differential Effects on Brain Acetylcholinesterase Activity and Memory in Rats." Life Sci. 77 (18): 2299-311.

[4] Herman, J. P., and Cullinan, W. E. 1997. "Neurocircuitary of Stresss: Central Control of the Hypothalamo-Pituitary-Adrenocortical Axis." Trends Neurosci. 20 (2): 78-84. 
[5] Badowska-Szalewska, E., Klejbor, I., Cecot, T., Spodnik, J. H., and Moryś, J. 2009. "Changes in NGF/c-Fos Double Staining in the Structures of the Limbic System in Juvenile and Aged Rats Exposed to Forced Swim Test." Acta Neurobiol. Exp. 69 (4): 448-58.

[6] Wang, L., Muxin, G., Nishida, H., Shirakawa, C., Sato, S., and Konishi, T. 2007. "Psychological Stress-Induced Oxidative Stress as a Model of Sub-healthy Condition and the Effect of TCM." Evidence-Based Complementary and Alternative Medicine 4 (2): 195-202.

[7] Frederiks, W. M., Marx, F., and Myagkaya, G. L. 1986. "A Histochemical Study of Changes in Mitochondrial Enzyme Activities of Rat Liver after Ischemia in Vitro." Virchows Arch. B-Cell Pathol. Incl. Mol. Pathol. 51 (1): 321-9.

[8] Nishida, T., Shibata, H., Koseki, M., Nakao, K., Kawashima, Y., Yoshida, Y., and Tagawa, K. 1987. "Peroxidative Injury of the Mitochondrial Respiratory Chain during Reperfusion of Hypothermic Rat Liver." Biochim. Biophys. Acta 890 (1): 82-8.

[9] Harris, J. J., Jolivet, R., and Attwell, D. 2012. "Synaptic Energy Use and Supply." Neuron 75 (5): 762-77.

[10] Burnstock, G. 2002. "Potential Therapeutic Targets in the Rapidly Expanding Field of Purinergic Signaling." Clin. Med. 2 (1): 45-53.

[11] Deli, T., and Csernoch, L. 2008. "Extracellular ATP and Cancer: An Overview with Special Reference to P2 Purinergic Receptors." Pathol. Oncol. Res. 14 (3): 219-31.

[12] Patel, R. P., Cornwell, T., and Darley-Usmar, V. M. 1999. "The Biochemistry of Nitric Oxide and Peroxynitrite: Implications for Mitochondrial Function.” In Understanding the Process of Aging: The Roles of Mitochondria, Free Radicals and Antioxidants, edited by Packer, L., and Cadenas, E. New York: Marcel Dekker, 39-56.

[13] Chan, S. W., Nguyen, P. N., Ayele, D., Chevalier, S., Aprikian, A., and Chen, J. Z. 2011. "Mitochondrial DNA Damage Is Sensitive to Exogenous $\mathrm{H}_{2} \mathrm{O}_{2}$ but Independent of Cellular ROS Production in Prostate Cancer Cells." Mutat. Res. 716: 40-50.

[14] Halliwell, B., and Aruoma, O. I. 1991. "DNA Damage by Oxygen Derived Species: Its Mechanism and Measurement in Mammalian Systems.” FEBS Letters 281: 9-19.

[15] Elderon, L., and Whooley, M. A. 2013. "Depression and Cardiovascular Disease.” Prog. Cardiovasc. Dis. 55 (6): 511-23.

[16] Pavel, S., Van Nieuwpoort, F., Van der Meulen, H., Out, C., Pizinger, K., Cetkovska, P., Smit, N. P. M., and Koerten, H. K. 2004. "Disturbed Melanin Synthesis and Chronic Oxidative Stress in Dysplastic Naevi.” Eur. J.
Cancer 40 (9): 1423-30.

[17] Powell, N. D., Tarr, A. J., and Sheridan, J. F. 2013. "Psychosocial Stress and Inflammation in Cancer." Brain Behav. Immun. 30: 41-7.

[18] Sutherland, M. A., Shome, G. P., Hulbert, L. E., Krebs, N., Wachtel, M., and McGlone, J. J. 2009. "Acute Stress Affects the Physiology and Behavior of Allergic Mice." Physiol. Behav. 98 (3): 281-7.

[19] Bai, H., Liu, R., Chen, H. L., Zhang, W., Wang, X., Zhang, X. D., Li, W. L., and Hai, C. X. 2014. "Enhanced Antioxidant Effect of Caffeic Acid Phenethyl Ester and Trolox in Combination against Radiation Induced-Oxidative Stress." Chem. Biol. Interact. 207: 7-15.

[20] Das, S., Das, J., Paul, A., Samadder, A., and Khuda-Bukhsh, A. R. 2013. "Apigenin, a Bioactive Flavonoid from Lycopodium clavatum, Stimulates Nucleotide Excision Repair Genes to Protect Skin Keratinocytes from Ultraviolet B-Induced Reactive Oxygen Species and DNA Damage." J. Acupunct. Meridian Stud. 6 (5): 252-62.

[21] Itoh, T., Ninomiya, M., Yasuda, M., Koshikawa, K., Deyashiki, Y., Nozawa, Y., Akao, Y., and Koketsu, M. 2009. "Inhibitory Effects of Flavonoids Isolated from Fragaria ananassa Duch on IgE-Mediated Degranulation in Rat Basophilic Leukemia RBL-2H3." Bioorg. Med. Chem. 17 (15): 5374-9.

[22] Parichatikanond, W., Suthisisang, C., Dhepakson, P., and Herunsalee, A. 2010. "Study of Anti-inflammatory Activities of the Pure Compounds from Andrographis paniculata (burm.f.) Nees and Their Effects on Gene Expression." Int. Immunopharmacol. 10 (11): 1361-73.

[23] Teiten, M. H., Gaascht, F., Dicato, M., and Diederich, M. 2013. "Anticancer Bioactivity of Compounds from Medicinal Plants Used in European Medieval Traditions." Biochem. Pharmacol. 86 (9): 1239-47.

[24] De Clercq, E. 2005. "Recent Highlights in the Development of New Antiviral Drugs." Curr. Opin. Microbiol. 8 (5): 552-60.

[25] Fabricant, D. S., and Farnsworth, N. R. 2001. "The Value of Plants Used in Traditional Medicine for Drug Discovery." Environ. Health Perspect. 109: 69-75.

[26] Khadri, A., Neffati, M., Smiti, S., Falé, P., Lino, A. R. L., Serralheiro, M. L. M., and Araujo, M. E. M. 2010. "Antioxidant, Antiacetylcholinesterase and Antimicrobial Activities of Cymbopogon schoenanthus L. Spreng. (Lemon Grass) from Tunisia.” Food Sci. Technol. 43 (2): 331-6.

[27] Khadri, A., Serralheiro, M. L. M., Nogueira, J. M. F., Neffati, M., Smiti, S., and Araujo, M. E. M. 2008. "Antioxidant and Antiacetylcholinesterase Activities of Essential Oils from Cymbopogon schoenanthus L. 


\section{Extract and Some of Its Active Compounds}

Spreng.: Determination of Chemical Composition by GC-Mass Spectrometry and ${ }^{13}$ C NMR.” Food Chem. 109 (3): 630-7.

[28] Le Floc'h, E. 1983. "Contribution to an Ethnobotanical Study of the Tunisian Flora." Tunisian Plant and Vegetation Program, Ministry of High Education and Scientific Research, Tunisia. (in French)

[29] Koba, K., Poutouli, P. W., Nenonene, Y. A., and Songai, M. S. 2007. "Chemical Composition and Anti-termite Activity of Three Tropical Essential Oils against Térmite Species Trinervitermes geminates." J. Sci. Technol. 5: 39-46.

[30] International Union for Conservation of Nature (IUCN). 2005. A Guide to Medicinal Plants in North Africa. Malaga: IUCN.

[31] Ketoh, G. K., Koumaglo, H. K., and Glitho, I. A. 2005. "Inhibition of Callosobruchus maculatus (F.) (Coleoptera: Bruchidae) Development with Essential Oil Extracted from Cymbopogon schoenanthus L. Spreng. (Poaceae), and the Wasp Dinarmus basalis (Rondani) (Hymenoptera: Pteromalidae)." J. Stored Prod. Res. 41 (4): 363-71.

[32] Othman, M. B., Han, J., El Omri, A., Ksouri, R., Neffati, M., and Isoda, H. 2013. "Antistress Effects of the Ethanolic Extract from Cymbopogon schoenanthus Growing Wild in Tunisia." Evidence-Based Complementary and Alternative Medicine. doi: 10.1155/2013/737401.

[33] Wani, W. Y., Sunkaria, A., Sharma, D. R., Kandimalla, R. J. L., Kaushal, A., Gerace, E., Chiarugi, A., and Gill, K. D. 2014. "Caspase Inhibition Augments Dichlorvos-Induced Dopaminergic Neuronal Cell Death by Increasing ROS Production and PARP1 Activation." Neuroscience 258: 1-15.

[34] Adams, M., Gmunder, F., and Hamburger, M. 2007. "Plants Traditionally Used in Age-Related Brain Disorders: A Survey of Ethnobotanical Literature." $J$. Ethnopharmacol. 113 (3): 363-81.
[35] Hunt, K. J., Coelho, H. F., Wider, B., Perry, R., Hung, S. K., Terry, R., and Ernst, E. 2010. "Complementary and Alternative Medicine Use in England: Results from a National Survey." Int. J. Clin. Pract. 64 (11): 1496-502.

[36] Mander, M. 1998. Marketing of Indigenous Medicinal Plants in South Africa: A Case Study in KwaZulu-Natal. Rome: FAO.

[37] Milton, N. G. 2004. "Role of Hydrogen Peroxide in the Aetiology of Alzheimer's Disease: Implications for Treatment." Drugs Aging 21 (2): 81-100.

[38] Ku, H. H., Brunkb, U. T., and Sohal, R. S. 1993. "Relationship between Mitochondrial Superoxide and Hydrogen Peroxide Production and Longevity of Mammalian Species." Free Radic. Biol. Med. 15 (6): 621-7.

[39] Salganik, R. I. 2001. "The Benefits and Hazards of Antioxidants: Controlling Apoptosis and Other Protective Mechanisms in Cancer Patients and the Human Population.” J. Am. Coll. Nutr. 20 (5): 464-72.

[40] Valko, M., Leibfritz, D., Moncol, J., Cronin, M. T. D., Mazur, M., and Telser, J. 2007. "Free Radicals and Antioxidants in Normal Physiological Functions and Human Disease.” Int. J. Biochem. Cell Biol. 39 (1): 44-84.

[41] Halliwell, B., and Gutteridge, J. M. C. 1985. Free Radicals in Biology and Medicine. Oxford: Clarendon Press.

[42] Khanduja, K. L., Avti, P. K., Kumar, S., Mittal, N., Sohi, K. K., and Pathak, C. M. 2006. "Anti-apoptotic Activity of Caffeic Acid, Ellagic Acid and Ferulic Acid in Normal Human Peripheral Blood Mononuclear Cells: A Bcl-2 Independent Mechanism.” Biochim. Biophys. Acta 1760 (2): 283-9.

[43] Lou, H., Jing, X., Ren, D., Wei, X., and Zhang, X. 2012. "Eriodictyol Protects against $\mathrm{H}_{2} \mathrm{O}_{2}$-Induced Neuron-Like PC12 Cell Death through Activation of Nrf2/ARE Signaling Pathway." Neurochem. Int. 61 (2): 251-7.

[44] Karakaya, S. 2004. "Bioavailability of Phenolic Compounds." Crit. Rev. Food Sci. Nutr. 44 (6): 453-64. 